\title{
Silver nanoparticle decorated poly(2-aminodiphenylamine) modified carbon paste electrode as a simple and efficient electrocatalyst for oxidation of formaldehyde
}

\author{
Reza Ojani*, Saeid Safshekan, Jahan-Bakhsh Raoof \\ Electroanalytical Chemistry Research Laboratory, Faculty of Chemistry, University of Mazandaran, Babolsar, Iran
}

\section{A R T I C L E I N F O}

Article history:

Received 31 January 2014

Accepted 16 April 2014

Published 20 September 2014

\section{Keywords:}

Electrocatalyst

Silver nanoparticle

Formaldehyde

2-Aminodiphenylamine

Carbon paste electrode

\begin{abstract}
A B S T R A C T
This work describes the promising activity of silver nanoparticles on the surface of a poly(2-amino diphenylamine) modified carbon paste electrode (CPE) towards formaldehyde oxidation. Electrodeposition of the conducting polymer film on the CPE was carried out using consecutive cyclic voltammetry in an aqueous solution of 2-aminodiphenylamine and $\mathrm{HCl}$. Nitrogen groups in the polymer backbone had a Ag ion accumulating effect, allowing Ag nanoparticles to be electrochemically deposited on the surface of the electrode. The electrochemical and morphological characteristics of the modified electrode were investigated. The electro-oxidation of formaldehyde on the surface of electrode was studied using cyclic voltammetry and chronoamperometry in aqueous solution of $0.1 \mathrm{~mol} / \mathrm{L} \mathrm{NaOH}$. The electro-oxidation onset potential was found to be around $-0.4 \mathrm{~V}$, which is unique in the literature. The effect of different concentrations of formaldehyde on the electrocatalytic activity of the modified electrode was investigated. Finally, the diffusion coefficient of formaldehyde in alkaline media was calculated to be $0.47 \times 10^{-6} \mathrm{~cm}^{2} / \mathrm{s}$ using chronoamperometry.
\end{abstract}

(C) 2014, Dalian Institute of Chemical Physics, Chinese Academy of Sciences. Published by Elsevier B.V. All rights reserved.

\section{Introduction}

The development of efficient electrocatalysts for oxidation of small organic molecules (such as $\mathrm{CH}_{3} \mathrm{OH}, \mathrm{HCOOH}$, and $\mathrm{HCHO}$ ) has received considerable attention owing to their great potential as fuels in clean and high-efficiency energy conversion devices [1-4]. Although HCHO is of less importance than methanol, the study of its electro-oxidation has attracted much attention mainly because of two aspects. First, HCHO is one of the intermediate products of methanol oxidation, so the study of its electrochemical oxidation is important for full understanding of methanol oxidation. The second aspect is the toxicity of HCHO, which is one of the major hazardous substances emitted from widely used construction and decorative materials. It also is widely used in the chemical, wood processing, paper, and textile industries, and in technologically important processes such as electroless copper plating. Long periods of exposure to levels of HCHO that exceed safe concentrations may cause adverse effects to human health [5]. The World Health Organization also identified HCHO as "Carcinogenic to humans" [6]. Among the various approaches that have been explored to conquer these challenges, one of the most important is the oxidation of $\mathrm{HCHO}$ to less harmful materials such as formic acid or $\mathrm{CO}_{2}$.

In recent years, many reports have been published on the oxidation of HCHO under a wide range of conditions and on various electrodes, although most have been carried out on $\mathrm{Pt}$ electrodes [7-16]. However, although Pt is one of the most efficient metal catalysts for oxidation of $\mathrm{HCHO}$, it is easily poisoned

\footnotetext{
* Corresponding author. Tel: +98-112-5342301; Fax: +98-112-5342302; E-mail: fer-o@umz.ac.ir This work was supported by Iranian Nanotechnology Society. 
by the CO-like intermediate produced from incomplete oxidation of the fuel. Another problem intrinsic to Pt is its high cost. One approach to solving these problems is the development of a cheaper, non-poisonable catalyst while maintaining high activity for the oxidation process. In this approach several reports have already been published on the surfaces of catalysts such as $\mathrm{Cu}$ [7], $\mathrm{Ni}[13,14]$, and $\mathrm{Ag}$ [17]. In the present work, we report the strong activity and high stability of Ag nanoparticles on the surface of poly(2-aminodiphenylamine) as a new, simple, and low cost electrocatalyst. HCHO oxidation at the surface of this electrocatalyst exhibits a very low over-potential in comparison with those of commonly used electrocatalysts such as Pt and Pd.

\section{Experimental}

\subsection{Reagent and materials}

The solvent used in this study was distilled water. Silver nitrate, sodium hydroxide, 2-aminodiphenylamine (2ADPA), and formaldehyde, all of analytical grade, were obtained from Merck and used without further purification. Hydrochloric acid ( $1 \mathrm{~mol} / \mathrm{L}$ ) prepared from the concentrated acid (Fluka) was used as the supporting electrolyte for electropolymerization. High viscosity paraffin (density: $0.88 \mathrm{~g} / \mathrm{cm}^{3}$ ) from Fluka was used as the pasting liquid for the carbon paste electrode (CPE). Graphite powder (particle diameter $=0.1 \mathrm{~mm}$ ) from Merck was used as the working electrode material.

\subsection{Instrumentation}

Cyclic voltammetry and chronoamperometry experiments were carried out using a potentiostat/galvanostat (Sama 500-C Electrochemical Analysis System, Sama, Iran) coupled with a Pentium IV personal computer for data acquisition. The electrochemical cell was assembled as a conventional three-electrode system with the nano-Ag/P(2ADPA)/CPE (3.4-mm diameter) as the working electrode, $\mathrm{Ag} / \mathrm{AgCl} / \mathrm{KCl}(3 \mathrm{~mol} / \mathrm{L})$ as the reference electrode (Metrohm), and platinum wire as the counter electrode.

\subsection{Preparation of CPE and $P(2 A D P A) / C P E$ electrodes}

A CPE was prepared by hand mixing $0.3 \mathrm{~mL}$ of paraffin oil and $1.0 \mathrm{~g}$ of graphite powder with a mortar and pestle until a uniformly wetted paste was obtained. A portion of the homogeneous paste was packed firmly into the bottom of a glass tube (internal radius $=1.7 \mathrm{~mm}$ ), and electrical contact was provided by a copper wire fitted into the glass tube. The surface of the electrode was smoothed on white paper and rinsed with distilled water prior to each experiment.

A P(2ADPA)/CPE electrode was fabricated using an electropolymerization technique according to our previous work [18]. In brief, a carbon paste electrode was immersed into a cell containing an aqueous solution of $1.0 \mathrm{~mol} / \mathrm{L} \mathrm{HCl}$ and $5 \mathrm{mmol} / \mathrm{L}$ 2ADPA. Poly(2ADPA) was electrochemically deposited on the surface of the CPE by applying consecutive cyclic voltammetry between -0.2 and $0.9 \mathrm{~V}$ at a scan rate of $100 \mathrm{mV} / \mathrm{s}$.

\section{Results and discussion}

\subsection{Preparation and characterization of nano- $A g / P(2 A D P A) / C P E$}

To deposit Ag nanoparticles onto the polymeric film, the freshly prepared P(2ADPA)/CPE was soaked in a well stirred $1.0 \mathrm{mmol} / \mathrm{L} \mathrm{AgNO}_{3}$ solution at open circuit for $10 \mathrm{~min}$. Accumulation of $\mathrm{Ag}^{+}$ions occurred by complex formation between $\mathrm{Ag}^{+}$and amine sites of the polymer backbone on the CPE. The electrode was then rinsed with distilled water and transferred into a cell containing $0.1 \mathrm{~mol} / \mathrm{L} \mathrm{NaOH}$ solution. The Ag nanoparticles were fixed on the surface of the electrode by applying consecutive potential cycling between -0.5 to $1.0 \mathrm{~V}$ at a scan rate of $100 \mathrm{mV} / \mathrm{s}$ until steady state voltammograms were obtained. Scheme 1 illustrates the overall modification process used to prepare the nano-Ag/P(2ADPA)/CPE.

The distribution of Ag nanoparticles over the electrode surface was observed by scanning electron microscopy (SEM) and energy dispersive X-ray spectroscopy (EDX). The white particles in Fig. 1(a) clearly show the deposited Ag nanoparticles, which were less than $150 \mathrm{~nm}$ in diameter. This coating of $\mathrm{Ag}$ at the surface of electrode was further confirmed by EDX analysis. As shown in Fig. 1(b), energy peaks at around 3.0 and $3.2 \mathrm{keV}$ were ascribed to characteristic peaks of Ag. These results indicate the successful preparation of the Ag/P(2ADPA)/CPE electrode.

Figure 2(a) shows the electrochemical behavior of the $\mathrm{Ag}$ nanoparticles at the surface of $\mathrm{P}(2 \mathrm{ADPA}) / \mathrm{CPE}$ in $0.1 \mathrm{~mol} / \mathrm{L}$

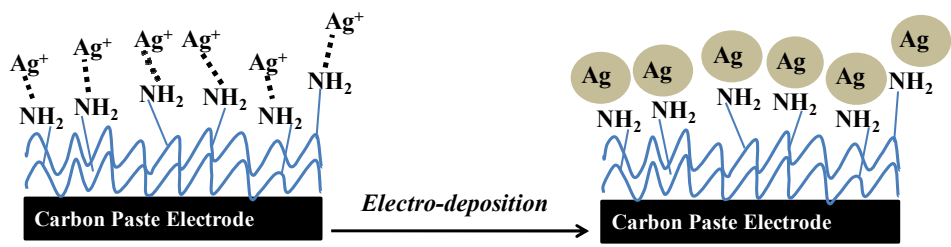

Scheme 1. Schematic of fabrication route to Ag/P(2ADPA)/CPE. 

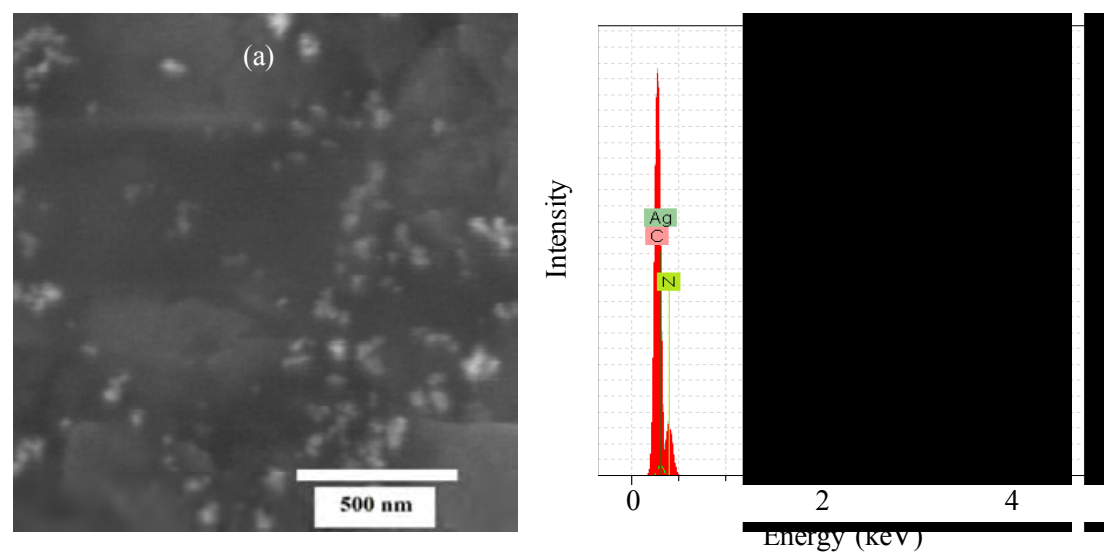

Fig. 1. SEM image (a) and EDX analysis (b) of Ag/P(2ADPA)/CPE.

$\mathrm{NaOH}$ solution at a scan rate of $20 \mathrm{mV} / \mathrm{s}$. The anodic and cathodic transitions observed in the voltammogram are in good agreement with those reported in the literature [19-24]. From the cyclic voltammogram depicted in Fig. 2(a) and those in the literature, a schematic pathway for the transitions occurring during the potential cycling can be presented as follows:

Anodic transitions:

$$
\begin{gathered}
\mathrm{Ag} \rightarrow \mathrm{Ag}(\mathrm{OH})_{2}{ }^{-} \rightarrow \mathrm{Ag}_{2} \mathrm{O} \\
\mathrm{Ag}
\end{gathered}
$$

Cathodic transitions:

$$
\begin{aligned}
& \mathrm{AgO} \rightarrow \mathrm{Ag}_{2} \mathrm{O} \\
& \mathrm{Ag}_{2} \mathrm{O} \rightarrow \mathrm{Ag}
\end{aligned}
$$

The first small anodic peak $\left(\mathrm{A}_{\mathrm{I}}\right)$, which appeared as a shoulder at around $0.2 \mathrm{~V}$, is related to the initial oxidation of $\mathrm{Ag}$ to $\mathrm{Ag}(\mathrm{OH})_{2}-$ through adsorption of $\mathrm{OH}^{-}$and desorption of the soluble species $\mathrm{Ag}(\mathrm{OH})_{2}{ }^{-}$, which diffuses away from the electrode surface [25].

$$
\mathrm{Ag}+2 \mathrm{OH}^{-}{ }^{-} \mathrm{ds} \rightarrow \mathrm{Ag}(\mathrm{OH})_{2}{ }^{-}{ }^{-}{ }^{-}+\mathrm{e}^{-}
$$
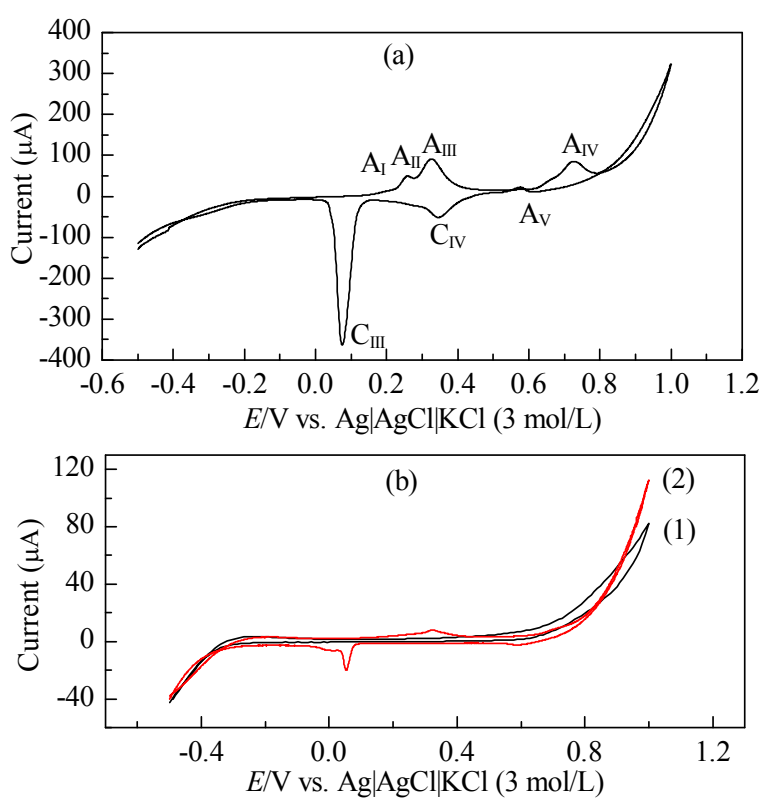

Fig. 2. (a) Typical cyclic voltammogram of Ag/P(2ADPA)/CPE in 0.1 $\mathrm{mol} / \mathrm{L} \mathrm{NaOH}$ solution (scan rate of $20 \mathrm{mV} / \mathrm{s}$ ); (b) Electrochemical behavior of $\mathrm{P}(2 \mathrm{ADPA}) / \mathrm{CPE}(1)$ and $\mathrm{Ag} / \mathrm{CPE}(2)$.

$$
\mathrm{Ag}(\mathrm{OH})_{2}{ }^{-} \text {ads } \rightarrow \mathrm{Ag}(\mathrm{OH})_{2}{ }^{-} \text {aq }
$$

The second small peak $\left(\mathrm{A}_{\mathrm{II}}\right)$ centered at about $0.25 \mathrm{~V}$ is attributed to the formation and precipitation of a monolayer of $\mathrm{Ag}_{2} \mathrm{O}$ from the supersaturated solution of $\mathrm{Ag}(\mathrm{OH})_{2}$, which progressively blocked off the dissolution reaction of $\mathrm{Ag}$ to $\mathrm{Ag}(\mathrm{OH})_{2}-[25]$.

The two major anodic peaks, AIII and AIv, located at about 0.32 and $0.73 \mathrm{~V}$ are related to the formation of multilayers of $\mathrm{Ag}_{2} \mathrm{O}$ and $\mathrm{AgO}$, respectively, according to the following equations [19]:

$$
\begin{aligned}
2 \mathrm{Ag}+2 \mathrm{OH}^{-} & \rightarrow \mathrm{Ag}_{2} \mathrm{O}+\mathrm{H}_{2} \mathrm{O}+2 \mathrm{e}^{-} \\
\mathrm{Ag}_{2} \mathrm{O}+2 \mathrm{OH}^{-} & \rightarrow 2 \mathrm{AgO}+\mathrm{H}_{2} \mathrm{O}+2 \mathrm{e}^{-}
\end{aligned}
$$

Conversely, during the cathodic sweep before the appearance of the first reduction peak, another anodic peak ( $\left.A_{v}\right)$ was observed. This could be attributed to continuous nucleation and growth of $\mathrm{Ag}_{2} \mathrm{O}$ film as a result of the direct electro-oxidation of Ag metal $[23,26]$. The two cathodic peaks, $\mathrm{C}_{\text {IV }}$ and $\mathrm{C}_{\text {III, }}$ observed during the reverse scan are attributed to the electroreduction of $\mathrm{AgO}$ to $\mathrm{Ag}_{2} \mathrm{O}$ and $\mathrm{Ag}_{2} \mathrm{O}$ to $\mathrm{Ag}$ metal, respectively.

The electrochemical behavior of P(2ADPA)/CPE was investigated to fully confirm the origins of the above oxidation and reduction peaks. As shown in Fig. 2(b), no observable anodic or cathodic peaks occurred for P(2ADPA)/CPE in alkaline medium. This fully proves that all redox peaks observed on $\mathrm{Ag} / \mathrm{P}(2 \mathrm{ADPA}) / \mathrm{CPE}$ are attributable to oxidation and reduction of deposited Ag nanoparticles according to the reactions described above. To clarify the effect of the poly(2-aminodiphenylamine) on the Ag deposition, the electrochemical behavior of $\mathrm{Ag} / \mathrm{CPE}$ was investigated in $0.1 \mathrm{~mol} / \mathrm{L} \mathrm{NaOH}$ solution (Fig. 2(b), curve (2)). It is obvious that the peak current of $\mathrm{Ag} / \mathrm{CPE}$ was much lower than that of Ag/P(2ADPA)/CPE, which confirms that the $-\mathrm{NH}$ and $-\mathrm{NH}_{2}$ functional groups of the polymer had an adsorptive effect on the Ag species.

\subsection{HCHO oxidation}

As we have previously reported, HCHO oxidation at $\mathrm{P}(2 \mathrm{ADPA}) / \mathrm{CPE}$ in $0.1 \mathrm{~mol} / \mathrm{L} \mathrm{NaOH}$ solution is very poor, and it is not possible to obtain oxidation before the discharge of the supporting electrolyte [18]. However, Ag nanoparticles at the surface of P(2ADPA)/CPE act as a catalyst for HCHO oxidation. 


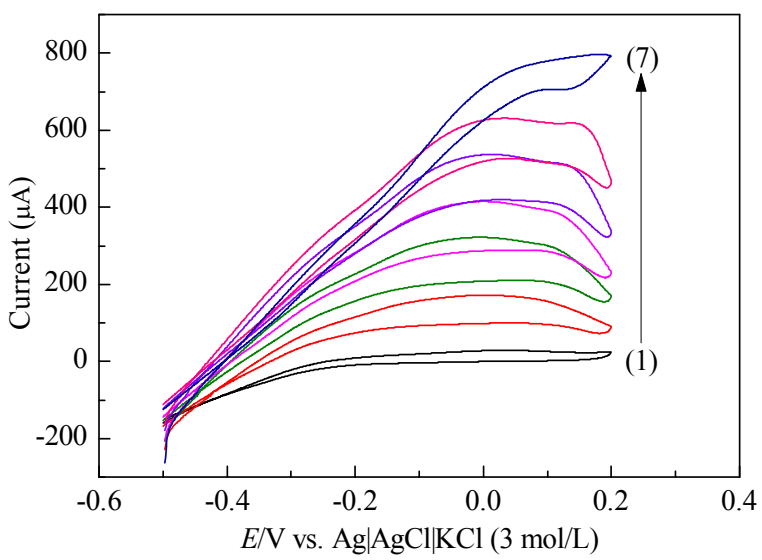

Fig. 3. Cyclic voltammograms of Ag/P(2ADPA)/CPE in $0.1 \mathrm{~mol} / \mathrm{L} \mathrm{NaOH}$ solution containing (1) 0.0 , (2) 0.013 , (3) 0.027 , (4) 0.04, (5) 0.067, (6) 0.094 , and (7) $0.17 \mathrm{~mol} / \mathrm{L}$ of formaldehyde. Scan rate of $20 \mathrm{mV} / \mathrm{s}$.

Figure 3 presents the electrochemical behavior of nano-Ag/ $\mathrm{P}(2 \mathrm{ADPA}) / \mathrm{CPE}$ in the absence and presence of different concentrations of $\mathrm{HCHO}$ at -0.5 to $0.2 \mathrm{~V}$. In this potential range the predominant species was metallic Ag and, as can be seen, the modified electrode did not display any anodic or cathodic peaks in the absence of $\mathrm{HCHO}$. In the presence of $\mathrm{HCHO}$, the oxidation process is well evidenced by the broad peak centered at around $-0.02 \mathrm{~V}$ and an onset potential of about $-0.4 \mathrm{~V}$. Increase in the concentration of $\mathrm{HCHO}$ caused a proportional enhancement in the anodic current, and the oxidation of $\mathrm{HCHO}$ continued during the cathodic half cycle, probably owing to oxidation of partially oxidized surface residues. It should be noted that in this potential range, $\mathrm{HCHO}$ oxidation takes place on pure metallic Ag nanoparticles, not on its oxidized species.

Table 1 shows a comparison of the nano-Ag/P(2ADPA)/CPE with other reported HCHO oxidation catalysts. The overpotential of $\mathrm{HCHO}$ oxidation over Ag is significantly lower than those reported in the literature for other metals, which shows that the Ag nanoparticles on the surface of P(2ADPA) had significantly higher electrocatalytic activity towards $\mathrm{HCHO}$ oxidation.

\subsection{Chronoamperometry studies}

Chronoamperometry offers more information about the electro-oxidation of $\mathrm{HCHO}$ at the surface of the modified electrode. Figure 4 shows typical current-time curves obtained in

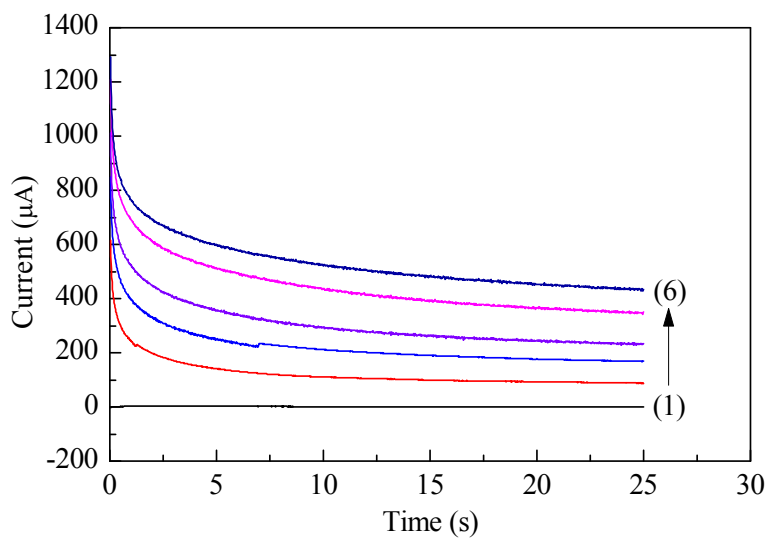

Fig. 4. Chronoamperograms obtained at $\mathrm{Ag} / \mathrm{P}(2 \mathrm{ADPA}) / \mathrm{CPE}$ in the absence (1) and the presence of 0.013 (2), 0.027 (3), 0.04 (4), 0.067 (5), and $0.094 \mathrm{~mol} / \mathrm{L} \mathrm{(6)} \mathrm{formaldehyde.} \mathrm{Electrode} \mathrm{potential} \mathrm{was} 0.0 \mathrm{~V}$ vs. $\mathrm{Ag}|\mathrm{AgCl}| \mathrm{KCl}(3 \mathrm{~mol} / \mathrm{L})$.

the absence and presence of different concentrations of $\mathrm{HCHO}$ at a set working electrode potential of $0.0 \mathrm{~V}$ vs. $\mathrm{Ag}|\mathrm{AgCl}| \mathrm{KCl}(3$ mol/L). As can be seen, the chronoamperograms are in good agreement with the cyclic voltammograms. No current was obtained in the absence of HCHO, while in the presence of $\mathrm{HCHO}$, an increase in the concentration of HCHO was followed by an increase in the oxidation current of the electrode. These results indicate the ability of the modified electrode to oxidize HCHO in alkaline media.

Chronoamperometry was also used to estimate the diffusion coefficient of HCHO. For an electroactive material with diffusion coefficient $D$, the current response under diffusion control is described by the Cottrell equation [29]:

$$
I=n F A D^{1 / 2} C \pi^{-1 / 2} t^{-1 / 2}
$$

Plotting the current as a function of the inverse square root of time gives a linear relationship (Fig. 5), indicating a diffusion controlled process. Using the slope of this straight line, the mean value for the diffusion coefficient of $\mathrm{HCHO}$ was found to be $0.47 \times 10^{-6} \mathrm{~cm}^{2} / \mathrm{s}$.

\subsection{Stability of electrode}

To evaluate the stability of the Ag/P(2ADPA)/CPE, a chronoamperometric experiment was carried out for a large time window (1500 s) in the presence of HCHO. Figure 6 shows that after applying a potential step of $0.0 \mathrm{~V}$, a rapid drop in anodic

Table 1

Comparison of the efficiency of Ag/P(2ADPA)/CPE for HCHO oxidation with those of previously reported electrodes.

\begin{tabular}{lccr}
\hline Electrocatalyst & Electrolyte & Potential $(\mathrm{V})$ & Reference \\
\hline Pt/PAANI/MWNTs/GCE & $0.5 \mathrm{~mol} / \mathrm{L} \mathrm{H}_{2} \mathrm{SO}_{4}$ & 0.414 & {$[8]$} \\
Pt-Pd/PPy-CNT & $0.5 \mathrm{~mol} / \mathrm{L} \mathrm{H}_{2} \mathrm{SO}_{4}$ & 0.64 & {$[12]$} \\
$\mathrm{Pt}-\mathrm{Pd} / \mathrm{CNT}$ & $0.5 \mathrm{~mol} / \mathrm{L} \mathrm{H}_{2} \mathrm{SO}_{4}$ & 0.63 & {$[27]$} \\
Pd-fMWNT & $0.1 \mathrm{~mol} / \mathrm{L} \mathrm{NaOH}$ & 0.71 & {$[11]$} \\
Pd-MWNT/GCE & $0.1 \mathrm{~mol} / \mathrm{L} \mathrm{NaOH}$ & 0.42 & {$[1]$} \\
$\mathrm{Pd}-\mathrm{CILE}$ & $0.1 \mathrm{~mol} / \mathrm{L} \mathrm{NaOH}$ & 0.15 & {$[9]$} \\
$\mathrm{Au}(111)$ & $0.5 \mathrm{~mol} / \mathrm{L} \mathrm{H}_{2} \mathrm{SO}_{4}$ & 0.65 & {$[28]$} \\
$\mathrm{Ru} / \mathrm{Au}(111)$ & $0.5 \mathrm{~mol} / \mathrm{L} \mathrm{H}_{2} \mathrm{SO}_{4}$ & 0.43 & {$[28]$} \\
$\mathrm{Ni}(\mathrm{OH})_{2} / \mathrm{POT}(\mathrm{TX}-100) / \mathrm{MCNTPE}$ & $0.1 \mathrm{~mol} / \mathrm{L} \mathrm{NaOH}$ & 0.70 & {$[13]$} \\
$\mathrm{Nano}-\mathrm{Ag} / \mathrm{P}(2 \mathrm{ADPA}) / \mathrm{CPE}$ & $0.1 \mathrm{~mol} / \mathrm{L} \mathrm{NaOH}$ & -0.02 & this work \\
\hline
\end{tabular}




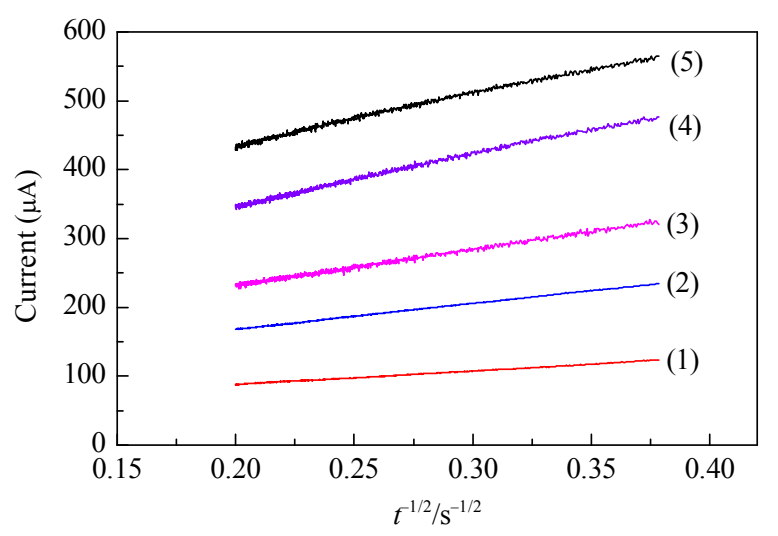

Fig. 5. Plot of $I$ versus $t^{-1 / 2}$ derived from the chronoamperogram data of Fig. 4. Formaldehyde concentration (mol/L): (1) 0.013; (2) 0.027; (3) 0.04; (4) 0.067; (5) 0.094 .

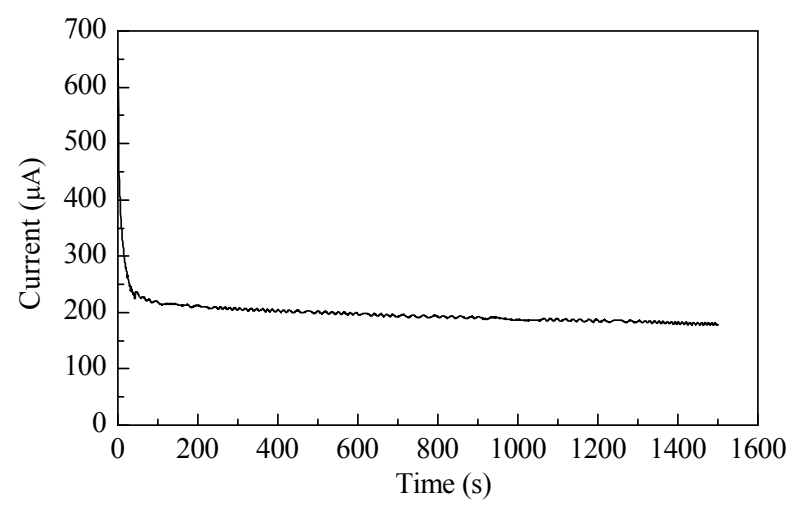

Fig. 6. Long-period chronoamperogram of the Ag/P(2ADPA)/CPE electrode in $0.04 \mathrm{~mol} / \mathrm{L} \mathrm{HCHO}+0.1 \mathrm{~mol} / \mathrm{L} \mathrm{NaOH}$ for period of $1500 \mathrm{~s}$. The electrode potential was $0.0 \mathrm{~V}$ vs. $\mathrm{Ag}|\mathrm{AgCl}| \mathrm{KCl}(3 \mathrm{~mol} / \mathrm{L})$.

current was obtained for about the initial $100 \mathrm{~s}$. This initial decrease was followed by a much slower decline such that the current after $1500 \mathrm{~s}$ was about $83 \%$ of that observed at $100 \mathrm{~s}$.
These results obviously indicate that the prepared catalyst had good stability toward HCHO.

\section{Conclusions}

We have investigated Ag nanoparticles on the surface of poly (2-amino diphenylamine) modified carbon paste electrode as an efficient and low cost electrocatalyst for oxidation of HCHO. In alkaline solution, the Ag nanoparticles exhibited a number of anodic and cathodic peaks corresponding to the $\mathrm{Ag} / \mathrm{Ag}(\mathrm{I})$ and $\mathrm{Ag}(\mathrm{I}) / \mathrm{Ag}(\mathrm{II})$ redox couples. HCHO oxidation commences on pure metallic Ag nanoparticles at potentials of around $-0.4 \mathrm{~V}$. The effect of different concentrations of HCHO on the electrocatalytic activity of this modified electrode was investigated and the proposed electrode exhibited an efficient electrocatalytic activity up to a HCHO concentration of 0.17 mol/L. Chronoamperometric experiments indicated that the prepared catalyst had good stability toward HCHO oxidation under the investigated conditions.

\section{References}

[1] Gao G Y, Guo D J, Li H L.J Power Sources, 2006, 162: 1094

[2] Hosseini M G, Abdolmaleki M, Ashrafpoor S. Chin J Catal (催化学 报), 2013, 34: 1712

[3] Parsons R, Vandernoot T. J Electroanal Chem Int Electrochem, 1988, 257: 9

[4] Kim J, Jung C, Rhee C K, Lim T H. Langmuir, 2007, 23: 10831

[5] Shen Y N, Yang X Z, Wang Y Z, Zhang Y B, Zhu H Y, Gao L, Jia M L. Appl Catal B, 2008, 79: 142

[6] IARC Monographs on the Evaluation of Carcinogenic Risks to Humans. Volume 88. Formaldehyde, 2-Butoxyethanol and 1-tertButoxypropan-2-ol. 2006

[7] Vaškelis A, Norkus E, Stalnioniene I, Stalnionis G. Electrochim Acta, 2004, 49: 1613

[8] Song C J, Khanfar M, Pickup P G. J Appl Electrochem, 2006, 36: 339

[9] Safavi A, Maleki N, Farjami F, Farjami E. J Electroanal Chem, 2009,

\section{Graphical Abstract}

Chin. J. Catal., 2014, 35: 1565-1570 doi: 10.1016/S1872-2067(14)60115-7

Silver nanoparticle decorated poly(2-aminodiphenylamine) modified carbon paste electrode as a simple and efficient electrocatalyst for oxidation of formaldehyde

Reza Ojani*, Saeid Safshekan, Jahan-Bakhsh Raoof

University of Mazandaran, Iran
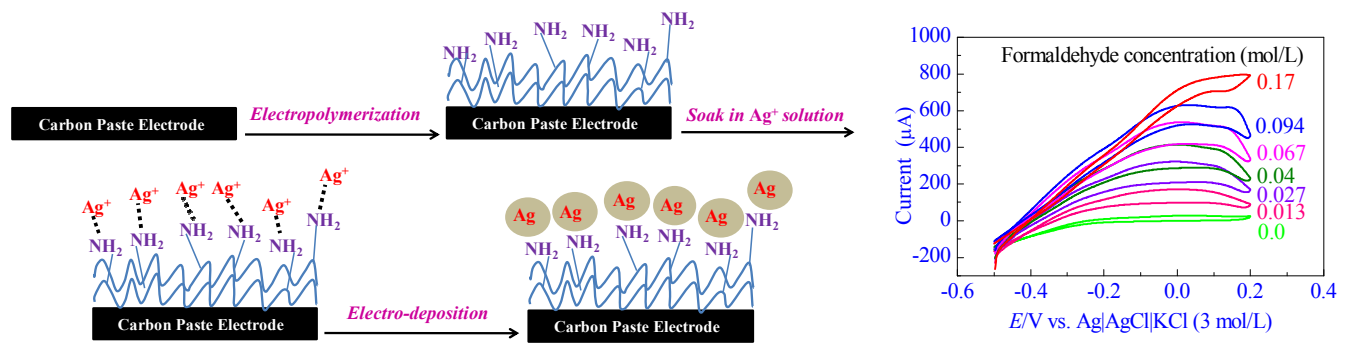

Ag nanoparticles were incorporated on poly-2ADPA modified carbon paste electrode and their electrochemical behavior in alkaline media was investigated. The Ag nanoparticles exhibited promising electrocatalytic activity for formaldehyde oxidation. 
626: 75

[10] Ojani R, Raoof J B, Safshekan S. J Appl Electrochem, 2012, 42: 81

[11] Zhu Z Z, Wang Z, Li H L.J Power Sources, 2009, 186: 339

[12] Selvaraj V, Alagar M, Sathish Kumar K. Appl Catal B, 2007, 75: 129

[13] Raoof J B, Ojani R, Abdi S, Hosseini S R. Int J Hydrogen Energy, 2012, 37: 2137

[14] Raoof J B, Omrani A, Ojani R, Monfared F. J Electroan Chem, 2009, 633: 153

[15] Geng J L, Bi Y P, Lu G X. Electrochem Commun, 2009, 11: 1255

[16] Villullas H M, Mattos-Costa F I, Nascente P A P, Bulhões L O S. Electrochim Acta, 2004, 49: 3909

[17] Wang L, Sun Y J, Che G B, Li Z. Appl Surf Sci, 2011, 257: 7150

[18] Ojani R, Raoof J B, Ahmady-Khanghah Y, Safshekan S. Int J Hydrogen Energy, 2013, 38: 5457
[19] Sato N, Shimizu Y. Electrochim Acta, 1973, 18: 567

[20] Droog J M M, Huisman F. J Electroanal Chem Int Electrochem, 1980, 115: 211

[21] Casella I G, Ritorti M. Electrochim Acta, 2010, 55: 6462

[22] Abd El Rehim S S, Hassan H H, Ibrahim M A M, Amin M A. Monatsh Chem, 1998, 129: 1103

[23] Majari Kasmaee L, Gobal F. J Power Sources, 2010, 195: 165

[24] Assaf F H, Zaky A M, Abd El Rehim S S. Appl Surf Sci, 2002,187: 18

[25] Ambrose J, Barradas R G. Electrochim acta, 1974, 19: 781

[26] Stonehart P. Electrochim Acta, 1968, 13: 1789

[27] Selvaraj V, Nirmala Grace A, Alagar M. J Colloid Interface Sci, 2009, 333: 254

[28] Strbac S, Avramov Ivic M. Electrochim Acta, 2009, 54: 5408

[29] Bard A J, Faulkner L R. Electrochemical Methods. New York: John Wiley and Sons, 2001 